(C) O. Shustov ${ }^{1}$

${ }^{1}$ Dnipro University of Technology, Dnipro, Ukraine

\title{
THE DEVELOPMENT OF TECHNOLOGY SCHEMES OF FORMATION OF EXTERNAL DUMP OF DIFFERENT TYPES OF ROCK IN LANDSLIDE CONDITIONS
}

\author{
(C) O.O. Шустов ${ }^{1}$
}

${ }^{1}$ Національний технічний університет «Дніпровська політехніка», Дніпро, Україна

\section{РОЗРОБКА ТЕХНОЛОГІЧНИХ СХЕМ ФОРМУВАННЯ ЗОВНІШНЬОГО ВІДВАЛУ РІЗНОТИПОВИХ ПОРІД В УМОВАХ ЗСУВОУТВОРЕННЯ}

Purpose. The scientific and practical purpose of the study is to develop and substantiate technological schemes for the formation of external dumps in conditions of impaired stability during the development of iron ore deposits.

Research methods. To solve the problem, the following research methods were used: geo-mechanical methods for studying changes in the stress-strain state, modeling of technological solutions by variants and graph-analytical method for calculating the stability of slopes for different variants for the development of work on the dump.

Findings. The use of the technique to determine the stability of the dump sides allowed to calculate the parameters and determine the prisms of possible landslide. The safety factors or different variants of work development are obtained, on the basis of which the most expedient way of restoration of dump works in conditions of the formed landslide is chosen. Technological schemes have been proposed and developed for the external dump No 2 of the Central Mining and Processing Plant, which allow to continue its operation in future.

Originality. When carrying out works in conditions of the formed landslide two variants of the further operation of a dump are modeled: a) with landslide removal without land allotment; $b$ ) without landslide removal with the formation of a supporting prism and with the land allocation. Geo-mechanical studies of changes in the stress-strain state in the area of landslide formation were carried out in order to forecast the risk of formation of new centers of geodynamic phenomena and develop measures to prevent them.

Practical implications. Based on the constructed sections of the dump and certain physical and mechanical properties, the safety factors were obtained for different variants for the development of works, which made enabled to determine the appropriate variant to eliminate the effects of the dump landslide. The developed technological schemes of development of works allow to operate safely an external dump No 2 of the PJSC Central Mining and Processing Plant.

Keywords: external dump, geo-mechanical researches, dump slope stability, landslide formation, physical and mechanical properties of rocks, technologies of resumption of work on a dump in the landslide conditions, technical and economic indicators.

Introduction. The development of sloping and steep mineral deposits is characterized by the widespread placement of overburden rocks to external dumps. The dump mass is mainly represented by rock varieties, which allows to form dumps of up to 80 - 120 meters height and more. The distance of dumps from quarries significantly affects the type of mechanization of dumps. Thus, when placing dumps at a distance of up to 
$5 \mathrm{~km}$ from the open mine, it is economically to carry out dump work with the delivery of overburden by dump trucks and stack them with bulldozers. Increasing the distance gives the advantage of moving the overburden rocks to the storage place by rail transport laying them using single-bucket excavators, mostly by mechanical shovels.

Technology, mechanization and organization of dumping is the basis of the dumping process in the open development of mineral deposits. The technical and economic indicators of mining equipment and open mine as a whole significantly depend on the clear and accident-free performance of dump work. The location of the dump within the mining allotment plays a crucial role in the choice of means for transportation of overburden rock, which in turn involves the level of mechanization of their storage. It should also be noted that when placing production waste in the worked-out space in the open mine, the easiest way to solve the issue of reclamation of disturbed lands, especially in agricultural. The operation of external dumps requires a certain alienation of the land surface to store industrial wastes. Such dumps in most cases have a fairly high height, which requires significant resources and funds for their reclamation [1].

Analysis of technological solutions on the research topic. The choice of location of external dumps depends on the type of the open mine field, terrain and value of disturbed lands, the scale of production of excavation works, engineering-geological, climatic and weather conditions. When developing deposits in the plains, as a rule, dumps are built on infertile lands, sloping hills, gorges, gullies, ravines, lowlands, previously worked out open mines, and so on. The main condition ensuring the dump stability is the preparation of its sole (removal of the upper layer of covering rocks and fencing with drainage ditches) and forced compaction of the rocks of the lower dump ledge to achieve stable rocks in geological cross section. To do this, the lower ledge should be formed of rocks with at least $20 \mathrm{~m}$ height [2]. At the same time, the average distance of transportation of overburden rocks usually does not exceed $9-10 \mathrm{~km}$.

The height of the dump is limited by the conditions of stability of its slopes and the sole on which it is placed. Based on this, the calculation of the main parameters of the dumps according to H.L. Fisenko is recommended to do taking into account the values of adhesion factors, the angle of internal friction, density and moisture of the rocks being formed. The stable slope angle of the dump tier is taken to be equal to the internal friction angle [3].

At iron ore quarries, where overburden rocks are transported by rail, dumps equipped with single-bucket straight mechanic shovels are mainly operated, which is due to the high lumpiness and strength of stored rocks. Detailed substantiation of their technological parameters was performed by M.H. Novozhilov [4] and specified by I.I. Ruskyi [5]. It has been found that the length of the dumps varies and depends entirely on the volume of the dead end for rock unloading. Usually in large quarries, two or more dumps are arranged, or one large one, which is divided into several sections, called dead ends.

The height of dump ledges depends on physical and mechanical properties of the stored rocks, sole drying degree, lumpiness, type of dumps, parameters of dump and transport equipment, system of their development, etc. On average, when storing clay, sand and rock by excavators, the height of dump ledges is from $15-20$ to $30-40 \mathrm{~m}$; 
by bulldozers $-10-15,15-20$ and 25-30 m, respectively [6].

Formulation of the problem. The considered technological solutions reveal the basic principles and schemes for formation of external dumps at the development of iron ore deposits. However, the process of external dump formation with the use of single-bucket excavators in conditions of disturbed stability of arrays is insufficiently studied. Therefore, the purpose of this study is to develop and substantiate technological schemes for the formation of external dumps in conditions of disturbed stability during the development of iron ore deposits.

Main part. In the development of technological schemes for the formation of the external dump in conditions of disturbed stability, two variants for further backfilling to the final circuits were considered: a) with the removal of the landslide without land allotment; b) without the removal of the landslide with the formation of a supporting prism and with the land allotment.

The proposed technological solutions are developed as a result of a landslide on the external dump No 2 of the Petrovskyy open mine of the PJSC Central Mining and Processing Plant.). Loose and rocky lands are stored in the dump, which are delivered by rail. In fact, the dump is poured in succession in several tiers. At the dump No 2, overburden rock is accepted at 2 dump dead ends and is dumped with the help of ЕКГ8I and EШ 10/70 excavators. At the moment, EШ No 1 is removed from the danger zone at a distance of $100 \mathrm{~m}$ after the occurrence of deformation in the form of a landslide $[7,8]$.

Thus, in 2017 on the site of the south-western side of the dump in s.a. $170-220$, hor. $+175 \ldots+125$ there were deformations manifested in the form of landslide with the following parameters [7, 9]: a) length along the edge $-410 \mathrm{~m}$; b) average depth $7 \mathrm{~m}$, maximal $-12 \mathrm{~m}$; c) the average landslide $-10 \mathrm{~m}$; d) volume is 850 thousand $\mathrm{m}^{3}$; e) the area of landslide spread is 85 thousand $\mathrm{m}^{2}$.

Parameters of the deformed slope:

design:

- height of the dump tier $-15 \mathrm{~m}$;

- slope angle of the dump tier $-35^{\circ}$;

- the resulting angle of inclination of the dump side $-23^{\circ}$.

Actual:

- the angle of inclination of the ledge slope along the break surface of $50^{\circ}$;

- the actual inclination angle of the side, after the landslide $-14^{\circ}$;

- the inclination angle of the side in the sloping part of the landslide $-11^{\circ}$.

Previously, no deformations were observed in this part of the dump.

The following reasons for the landslide formation should be distinguished among the main ones:

a) complicated relief and the presence of a gully under the dump, which is characterized by variable rises.

b) low strength of clays that make up the dump, as well as high plasticity of clays at natural humidity of $20-24 \%$.

c) high humidity of the sole of the dump and high pressure of the dump on the flooded area, low strength of the rocks of the dump sole. 
As of 2018, the deformation had the following form (Fig. 1).

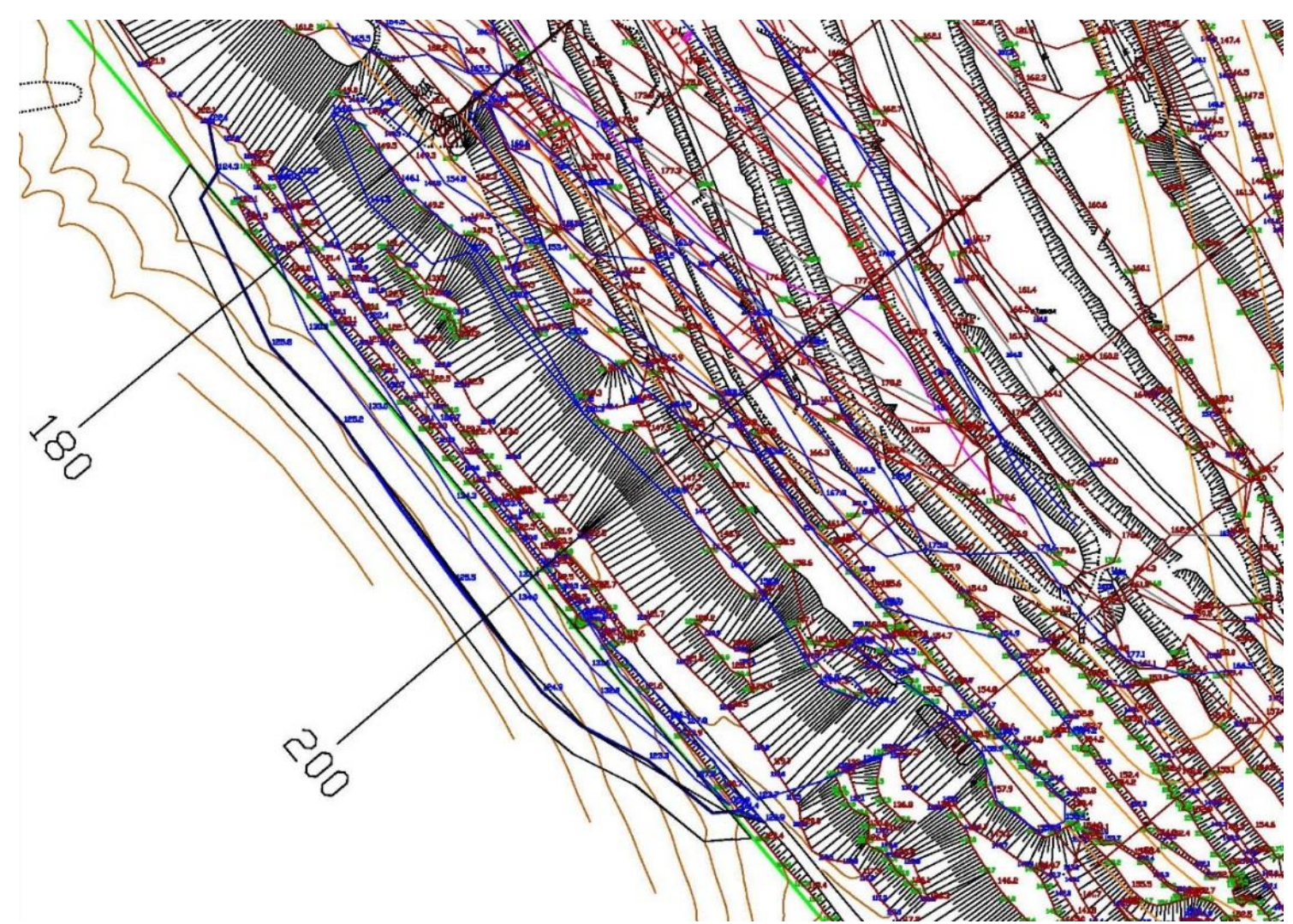

Fig. 1. Landslide plan with the position of the sections 180,200

According to the first variant, it is necessary to remove the rocks from the landslide array in such a way as to be able to restore the inspection road in the existing contours of the land allotment and to build a drainage ditch [7].

For this purpose, it is necessary to remove a part of landslide rocks from the top tiers $(+160 \ldots+175 \mathrm{~m},+150 \ldots+160 \mathrm{~m})$, to remove a part of rocks of the bottom tier with a dragline excavator, to form an embankment in a sole of an unstable site in s.a. 180 and remove the remnants of rocks in the dump sole.

The work is carried out in four stages.

1 stage. The slope of the dump is unloaded by removing two tiers of the dump to the horizons of +150.0 and $+160.0 \mathrm{~m}$. The work is carried out by an inverted shovel excavator with loading into dump trucks and removal of rocks to the dump sites.

Stage 2. The road from the dump entrance to the landslide is built and the stop prism is formed with the help of the rocks that formed the landslide, and other rocks of the landslide are removed with removal to the dump. The work is made by an inverted shovel excavator, dump trucks, bulldozer.

Stage 3. With the help of the EШ 10/70 excavator, the slope of the dump is laid out on a site with a steep slope.

Stage 4 (Formation of a drainage ditch). The drainage ditch located on the plan is formed by the inverted shovel excavator. The rock mass is placed on the external part of the dump. The ditch has the following dimensions: depth $1.5 \mathrm{~m}$, width $1.0-1.5 \mathrm{~m}$ at the base, slopes $35-40^{\circ}$. Cross section with an area of $4.7-4.9 \mathrm{~m}^{2}$. When forming the 
bypass channel with a length of $480 \mathrm{~m}$, the volume of excavation works will be 2352 $\mathrm{m}^{3}$. With the capacity of the inverted shovel excavator (bucket capacity $2.7 \mathrm{~m}^{3}$ ) $245 \mathrm{~m}^{3}$ / hour, the time for the bypass channel will be 9.6 hours (1.0 shift).

The rock from the of breast of the drainage ditch is removed to the dump and unloaded with dump trucks on the dump with the use of a bulldozer is planned on the site or pushed down under the slope.

VARIANT 2 (without landslide with the prism formation). The overburden rocks are delivered mainly by railway transport. In the process of forming the prism, delivery from the excavator reloading point to the landslide place is carried out with dump trucks. The prism is formed by a bulldozer. The number of dump trucks is the same as in the first variant, taking into account the length of transportation and productivity of the excavator placed at the reloading point of the dump [7].

\section{Construction of a prism of a dump additional uploading.}

The rock mass brought by motor transport is placed on the prism site and then the additional uploading prism is formed by a bulldozer. The formation of the additional uploading prism begins with the formation of a pioneer embankment. Dump trucks unload the rock mass into piles and the bulldozer forms a pioneer embankment. Upon reaching the site on the horizon with a mark of $+145.0 \mathrm{~m}$, the additional uploading prism of privatization is formed on the plane.

According to the first variant of dump formation, the removal of the landslide to the boundary of the land allotment is foreseen. Landslide removal only is not possible due to the reduced stability of the upper tiers. To reduce the load on the dump, the variant of removal of the rock part on the upper horizons between the marks +175 to $+160 \mathrm{~m}$ is considered.

The area which is prone to sliding in the section s.a. 180 (marked with cells) (Fig. 2). To reduce the pressure from the upper rocks in the area of $160 \mathrm{~m}$, it is necessary to remove the rocks on another horizon with marks from $+160,0$ to $+150.0 \mathrm{~m}$, part of the rocks is removed.

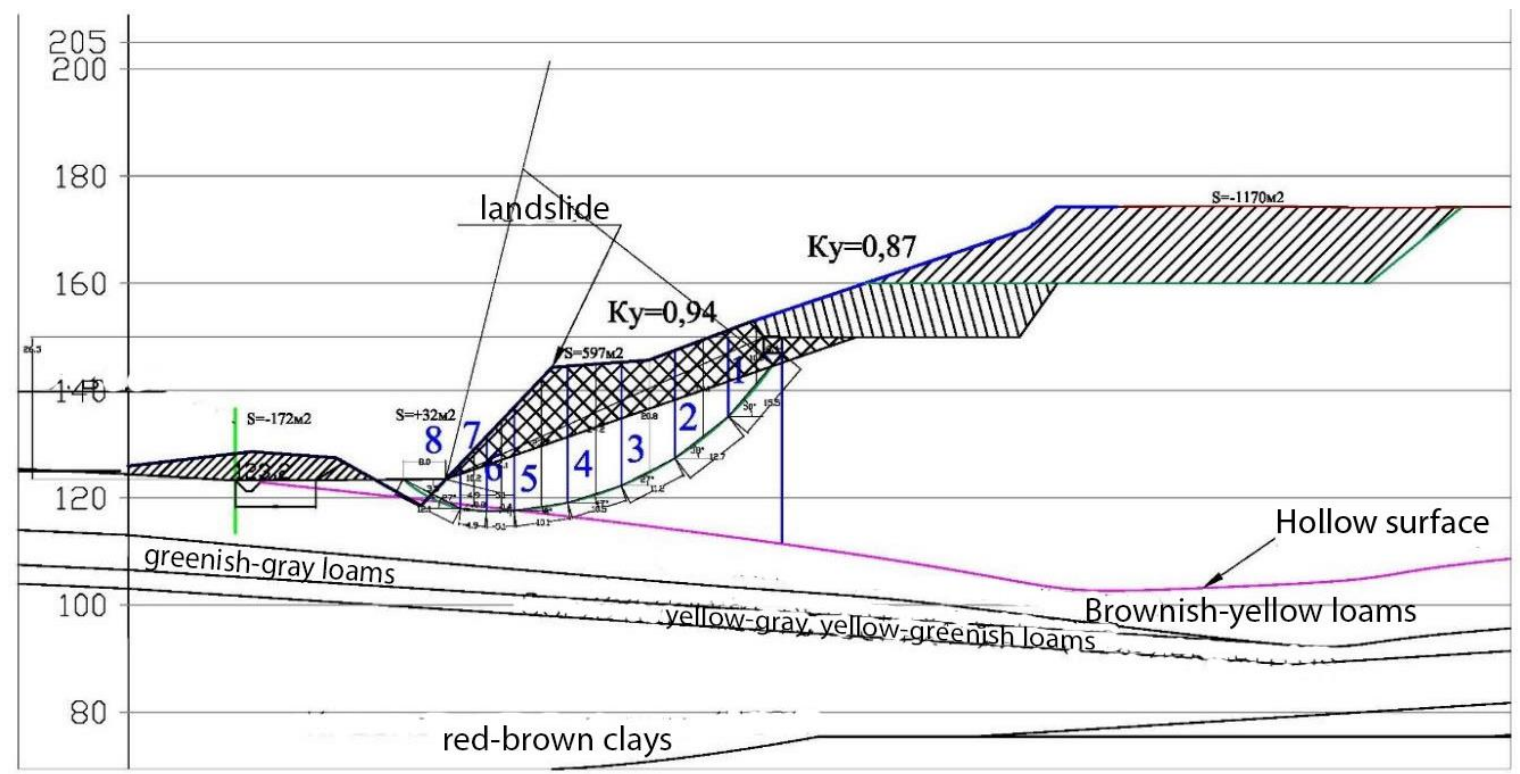

Fig. 2. Tiered removal of the overburden rocks for unloading the lower horizons 
It is also proposed to carry out backfilling with a prism at the base of this area after unloading the dump from the rocks of the upper horizons on the area between the surveying sections s.a. 180 and s.a. 190 (Fig. 3).

It is proposed to remove the dump and return it within the limits of the land allotment on a site between sections s.a. 180 s.a. 190 to carry out a set of measures.

Namely, the excavation of a part of the dump rocks in layers with the marks of the first excavation tier +174.0 and $+160.0 \mathrm{~m}$ and the second tier in the area between the sections of the s.a. 180 s.a. 190 marked with +160.0 and $+150.0 \mathrm{~m}$.

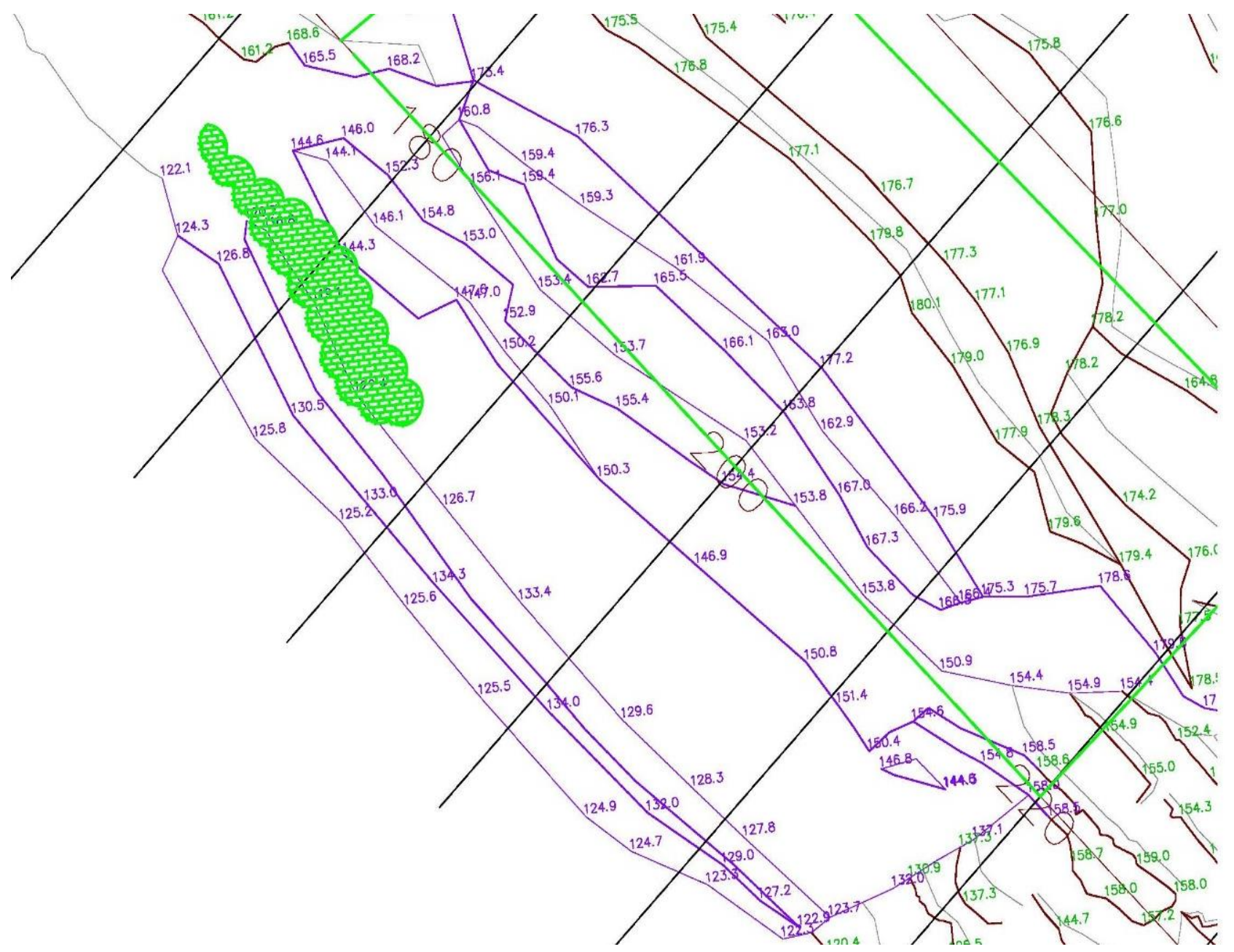

Fig. 3. The scheme of formation of a persistent prism and removal of dump rocks between horizons +160.0 and +150.0

To increase the safety factor, it is proposed to move the landslide rocks to the base of the dump and form a supporting prism with an upper mark of $+129 \mathrm{~m}$. The height of the support prism is $9.0 \mathrm{~m}$. Landslide rocks are removed by an excavator, moved by dump trucks to the bottom of the dump and the supporting prism is formed by a bulldozer. The width of the prism at the top is $20 \mathrm{~m}$.

According to the two variants for the development of dump work, the calendar plans for the further backfilling are adjusted, which are presented in the Figures 4 and 5. 


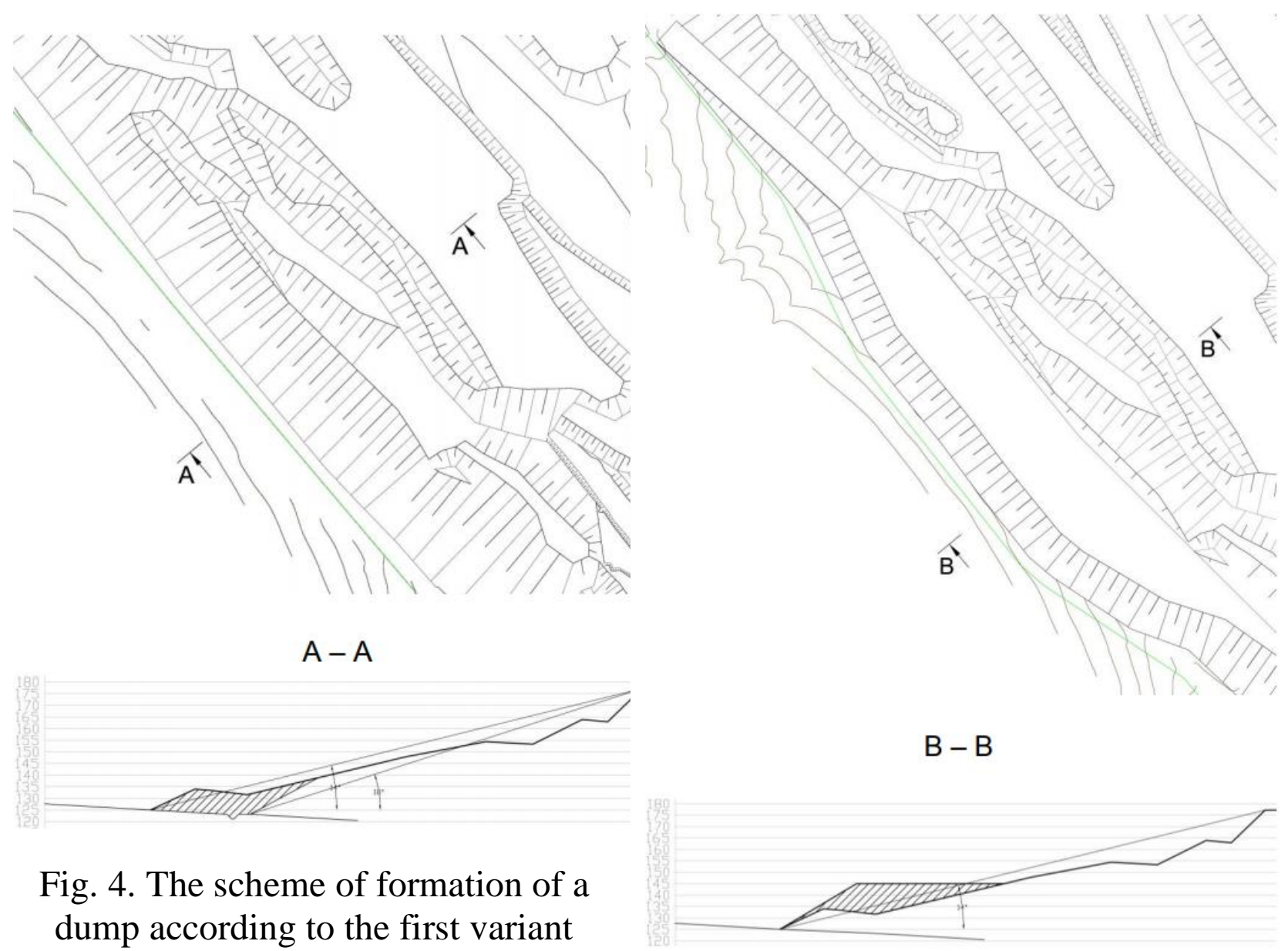

(with landslide removal)

Fig. 5. Scheme of dump formation according to the second variant (without landslide removal)

The plan of works on formation of an external dump according to the second variant is shown in the Figure 6 . To determine the order of filling the residual capacity of the dump, diagrams of the dependence of the volume of the fillingback from the height of the dumping tiers (dump), respectively, according to the first (Fig. 7) and second variants (Fig. 8).

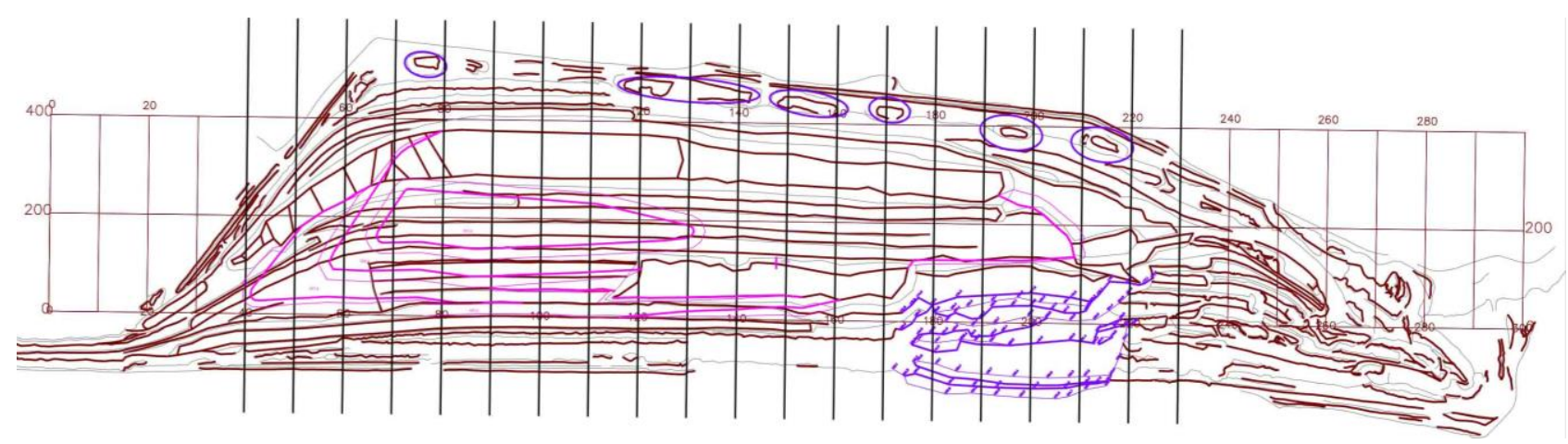

Fig. 6. The scheme of formation of the dump No 2 of the Petrovsky open mine to the final circuit according to the second variant. 


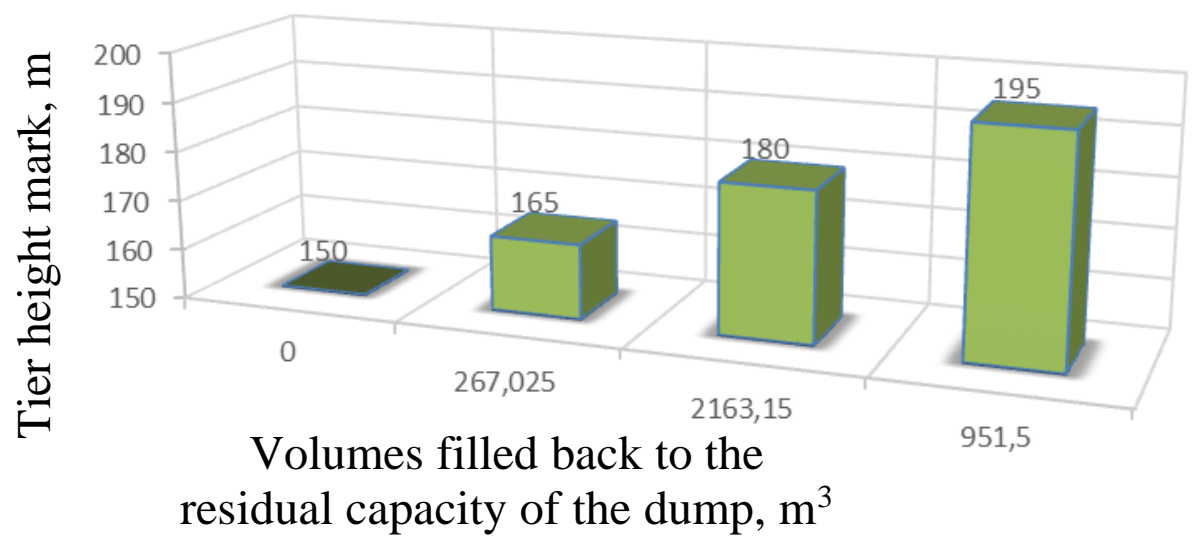

Fig. 7. The diagram of dependence of volumes of fillingback the overburden rocks in residual capacity of a dump from the dump tier height according to the first variant

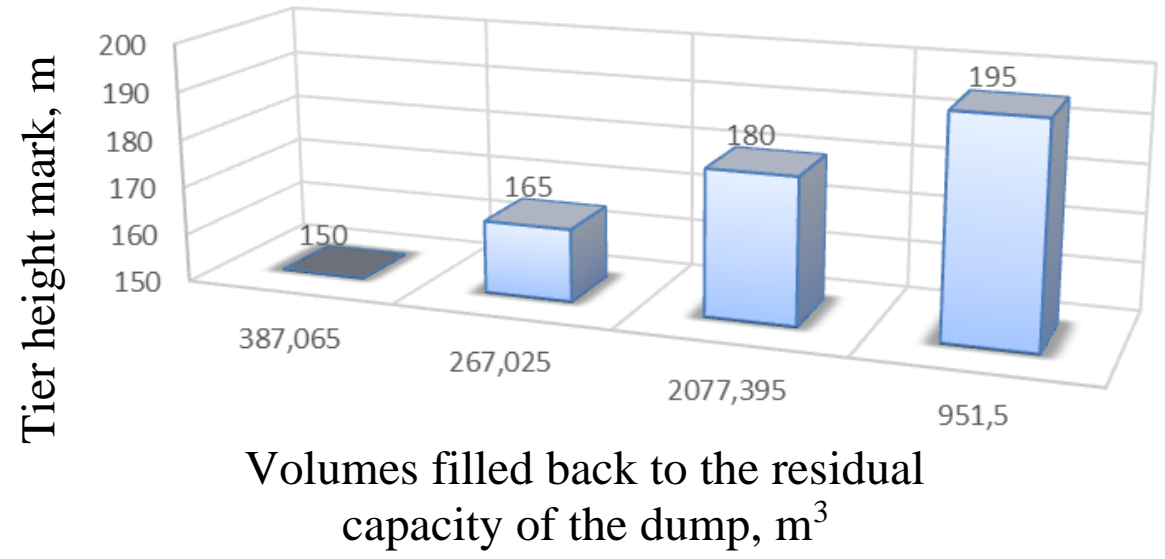

Fig. 8. The diagram of dependence of volumes of fillback of overburden rocks in residual capacity of the dump from the dump tier height according to the second variant

As can be seen from the diagram in the Figure 8, the second variant of the formation of the dump to the final contours allows to place additionally about 390 thousand $\mathrm{m}^{3}$ of the overburden rocks in the dump base for the formation of the supporting prism.

\section{Conclusions.}

1. Removal of the landslide to the boundaries of the land allotment can lead to repeated manifestations of rock displacement. The dump will be in the marginal equilibrium, which is dangerous for machinery and people working at the base of the dump. Regarding the technological decisions, the second variant which allows to place addition volumes of overburden rocks both in additionally uploaded embankment (385.14 thousand $\mathrm{m}^{3}$ ) and to form a dump along the height within the design contours with maintenance of the dump stability of a dump is the most effective.

2. When forming the dump taking into account the formed landslide, there are two solutions for further construction: the first one is reduction of the dump height with 
observance of the resulting slope angle within 16 degrees and the second - construction of additional uploaded embankments in the formed landslide area. Additional uploaded embankments reduce the resulting angle and create an additional load for the holding forces.

3. In 2020, it is recommended to place overburden rocks with a volume of 385.14 thousand $\mathrm{m}^{3}$ up to the mark of $+145 \mathrm{~m}$ with the use of dump trucks on the land area formed by landslide $(2.5 \mathrm{ha})$. This will increase the service life of the dump by 1 year. A drainage ditch $5 \mathrm{~m}$ wide and $2 \mathrm{~m}$ deep should be provided around the formed embankment, as well as an inspection road of $4.5 \mathrm{~m}$ width. The construction period of the ditch and the road is 9 days. The temporary road of 4.5 width and $2 \mathrm{~km}$ length is provided for the access of technological transport to the embankment. The road construction period is 3 days.

4. On the basis of the performed researches new design contours of dump formation are established according to two variants. Thus, the residual capacity of the dump No 2 of the Petrovsky open mine of the PJSC "Central Mining and Processing Plant" during its development according to the first variant is 3.6 million $\mathrm{m}^{3}$, and according to the second -4 million $\mathrm{m}^{3}$, and its service life is 6 and 7 years, respectively.

\section{References}

1. Дриженко, А.Ю. (2011). Карьерные технологические горнотранспортные системы: монография. Національний гірничий університет.

2. Дриженко, А.Ю. (1985). Восстановление земель при открытых разработках: монография. Недра.

3. Фисенко, Г.Л. (1965). Устойчивость бортов карьеров и отвалов. 2-е изд. перераб. и доп. Недра.

4. Новожилов, М.Г. (1961). Открытые горные работы: учеб. Госгортехиздат.

5. Русский, И.И. (1979). Технология отвальных работ и рекультивация на карьерах: монография. Недра.

6. Томаков, П.И. \& Наумов, И.К. (1992). Технология, механизация и организащия открытых горных работ: монография. МГИ.

7. Babets, Y., Anisimov, O., Shustov, O., Komirna, V., \& Melnikova, I. (2021). Determination of economically viable option of liquidation the consequences of external dump deformation. E3S Web of Conferences, 280, 08014. https://doi.org/10.1051/e3sconf/202128008014

8. Дриженко, А. Ю., Адамчук, А. А., Тамуя, С. А., \& Тельнов, В. Г. (2018). Дослідження параметрів внутрішніх відвалів у виробленому просторі відпрацьованих глибоких кар'єрів. Збірник Наукових Пращь Національного Гірничого Університету, 53, 56-65.

9. Pavlychenko, A., Adamchuk, A., Shustov, O., \& Anisimov, O. (2020). Justification of dump parameters in conditions of high water saturation of soils. Technology Audit and Production Reserves, 6(3(56)), 22-26.

https://doi.org/10.15587/2706-5448.2020.218139

\section{АНОТАЦІЯ}

Мета. Науково-практичною метою дослідження $\epsilon$ розробка та обгрунтування технологічних схем формування зовнішніх відвалів в умовах порушеної стійкості при відпрацюванні залізорудних родовищ. 
Методика досліджень. Для вирішення проблеми застосовані наступні методи дослідження: геомеханічні методи дослідження змін напружено-деформованого стану, моделювання технологічних рішень за варіантами та графо-аналітичний метод для розрахунків стійкості укосів за різними варіантами розвитку робіт на відвалі.

Результати дослідження. Використання методики для визначення стійкості бортів відвалу дозволило розрахувати параметри і визначити призми можливого зсуву. Отримані коефіцієнти запасу стійкості для різних варіантів розвитку робіт, на основі яких обраний найбільш доцільний спосіб відновлення відвальних робіт в умовах утвореного зсуву. Для зовнішнього відвалу №2 Центрального ГЗК запропоновані та розроблені технологічні схеми, які дозволяють в подальшому продовжити його експлуатацію.

Наукова новизна. При ведені робіт в умовах утвореного зсуву змодельовані два варіанти подальшої експлуатації відвалу: а) з прибиранням зсуву без відведення земель; б) без прибирання зсуву з формуванням підпірної призми та з відведенням земель. Проведені геомеханічні дослідження змін напружено-деформованого стану в районі утворення зсуву з метою прогнозної оцінки ризику формування нових осередків геодинамічних явищ і розробки заходів щодо їх запобігання.

Практичне значення. На основі побудованих розрізів відвала і визначених фізико-механічних властивостей були отримані коефіцієнти стійкості за різними варіантами розвитку робіт, що дало можливість визначити доцільний варіант ліквідації наслідків зсувних деформацій відвалу. Розроблені технологічні схеми розвитку робіт дозволяють безпечно експлуатувати зовнішній відвал №2 ПАТ «ЦГЗК».

Ключові слова: зовнішній відвал, геомеханічні дослідження, стійкість укосу відвалу, утворення зсуву, фізико-механічні властивості гірських порід, технології поновлення роботи на відвалі в умовах зсуву, техніко-економічні показники.

\section{АННОТАЦИЯ}

Цель. Научно-практическая цель исследования - разработка и обоснование технологических схем формирования внешних отвалов в условиях нарушенной устойчивости при отработке железорудных месторождений.

Методика исследований. Для решения проблемы применены следующие методы исследования: геомеханические методы исследования изменений напряженно-деформированного состояния, моделирование технологических решений по вариантам и графо-аналитический метод для расчетов устойчивости откосов по разным вариантам развития работ на отвале.

Результаты исследования. Использование методики определения устойчивости бортов отвала позволило рассчитать параметры и определить призмы возможного обрушения. Получены коэффициенты запаса устойчивости для различных вариантов развития работ, на основе которых выбран наиболее предпочтительный способ восстановления отвальных работ в условиях оползня. Для внешнего отвала №2 Центрального ГОКа предложены и разработаны технологические схемы, позволяющие в дальнейшем продолжить его эксплуатацию.

Научная новизна. При ведении работ в условиях образованного оползня смоделированы два варианта дальнейшей эксплуатации отвала: а) с уборкой оползня без отвода земель; б) без уборки оползня с формированием подпорной призмы и с отводом земель. Проведены геоме- 
ханические исследования изменений напряженно-деформированного состояния в районе образования оползня с целью прогнозной оценки риска формирования новых очагов геодинамических явлений и разработки мероприятий по их предотвращению.

Практическое значение. На основе построенных разрезов отвала и определенных физикомеханических свойств были получены коэффициенты устойчивости по разным вариантам развития работ, что позволило определить целесообразный вариант ликвидации последствий сдвиговых деформаций отвала. Разработанные технологические схемы развития работ позволяют безопасно эксплуатировать внешний отвал №2 ПАО «ЦГОК».

Ключевые слова: внешний отвал, геомеханические исследования, устойчивость откоса, образование оползня, физико-механические свойства горных пород, технологии возобновления работы на отвале в условиях оползня, технико-экономические показатели. 